\title{
Evaluation of Sexual Dimorphism of Foramen Magnum: A Morphometric Study
}

\author{
Pinki Kumari ${ }^{1}$, Aman Kumar², Sanjeev Kumar ${ }^{3}$, Saroj Kumar Ranjan ${ }^{4}$ \\ ${ }^{1}$ Tutor, Department of FMT, IGIMS, Patna, Bihar, ${ }^{2}$ Prof \& HOD, Department of FMT, IGIMS, Patna, Bihar, ${ }^{3}$ Associate Professor, Department of FMT, IGIMS, Patna, \\ Bihar.
}

\section{Abstract}

Background: Sex determination from skull morphology is important in medico-legal cases. The foramen magnum is an important structure of the skull base and is of particular interest for forensic experts. Aim: In this study the foramen magnum was analyzed for sex differences using standard osteometric techniques for the North Indian Population. Subjects and Methods: This study included 100 completely ossified dry human skull $(\mathrm{M}=\mathrm{F})$ in good condition with a record of sex. The cranial base was visually assessed for foramen magnum shape. Morphometry was determined using vernier caliper and the differences amongst gender were ascertained. Results: Oval shape was the most common followed by round, tetragonal and pentagonal in both sex. The results demonstrated that sexual dimorphism is present in the foramen magnum. APD and TD were higher in male skulls than females. Conclusion: In incomplete skeletons, metric analysis of the foramen magnum may provide a statistically useful indication as to sex of the unknown skull.

Keywords: Foramen Magnum, Shape, Anterioposterior Diameter, Transverse Diameter, Sexual Dimorphism.

Corresponding Author: Dr. Saroj Kumar Ranjan, Tutor, Department of FMT, IGIMS, Patna, Bihar.

Received: July 2019

Accepted: August 2019

\section{Introduction}

Sex determination from skull morphology is important in medico-legal cases. In most of the forensic studies the incomplete availability of skeletal remains makes gender identification difficult. The foramen magnum is an important structure of the skull base and is of particular interest to anthropologist, anatomist, and forensic experts. The importance of foramen magnum for gender differentiation is well established. ${ }^{[1-4]}$ Foramen magnum shows ethnic, racial and gender dimorphism in its dimensions and shapes. ${ }^{[5-9]}$ Shapes of the foramen magnum have been classified by Murshed into eight different shapes: oval, egg, round, tetragonal, pentagonal, hexagonal, irregular $\mathrm{A}$, and irregular $\mathrm{B} \cdot{ }^{[10-14]}$ Updating temporal changes of skull morphometry is essential for forensic study and anthropologists. The size and shape of the foramen magnum in the North Indian Population is largely unknown. Hence, the focus of this research was to evaluate the gender dimorphism in the morphometry and shape of foramen magnum in human skulls of North Indian Population.

\section{Subjects and Methods}

The study was conducted at Indira Gandhi Institute of Medical Sciences, Sheikhpura, Patna, using 100 fully ossified and dry adult human skulls (males=50 and
Females $=50$ ). The study was approved by institutional research committee. The skulls were collected from the department of anatomy. All the skulls were gender identified in the record. Only skulls with good conditions were included in the study. The samples with damaged, incomplete or without identification were not included in the study.

All the cranial bases were visually assessed for foramen magnum shape classification. Each shape of the foramen was observed, compared to pretested shape models and recorded as one of the four shapes, oval, round, tetragonal, pentagonal. The Anterioposterior diameter (= distance between Opisthion to Basion along the midsagittal plane) and Transverse diameter (= margins of the foramen at its junction with the posterior ends of the occipital condyles) of the foramen magnum was measured using digital venire caliper. The differences in antero-posterior and transverse dimensions of foramen magnum amongst gender were assessed. Data obtained were analyzed using Statistical Package for Social Sciences (SPSS) for windows version 10.00 .

\section{Results}

The shape of the foramen magnum was observed in all the 100 skulls and recorded. The overall incidence of the shapes of the Foramen Magnum is shown in [Figure 1]. 


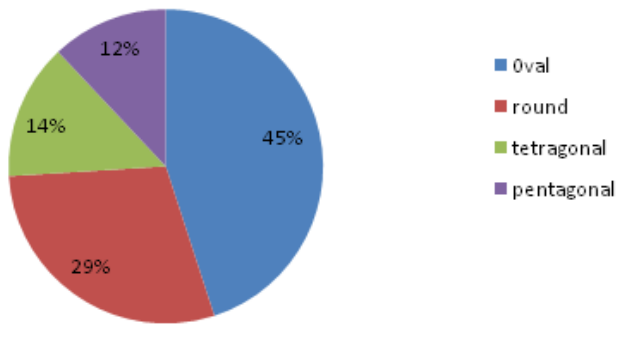

Figure 1: Incidence of the shapes of the Foramen Magnum

The most common shape was oval and the least common was the pentagonal shape. [Figure-2]

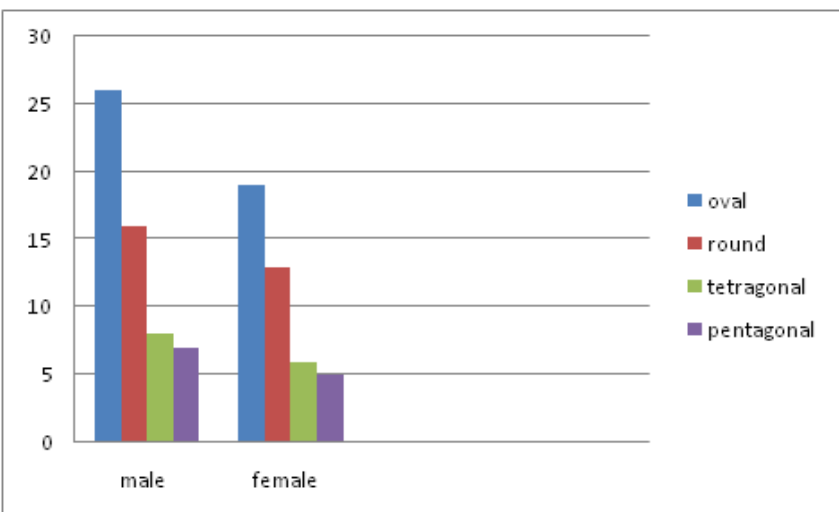

Figure 2: Showing gender wise distribution of the shapes of the foramen magnum

The morphometric analysis of the foramen magnum is shown in [Figure-3].

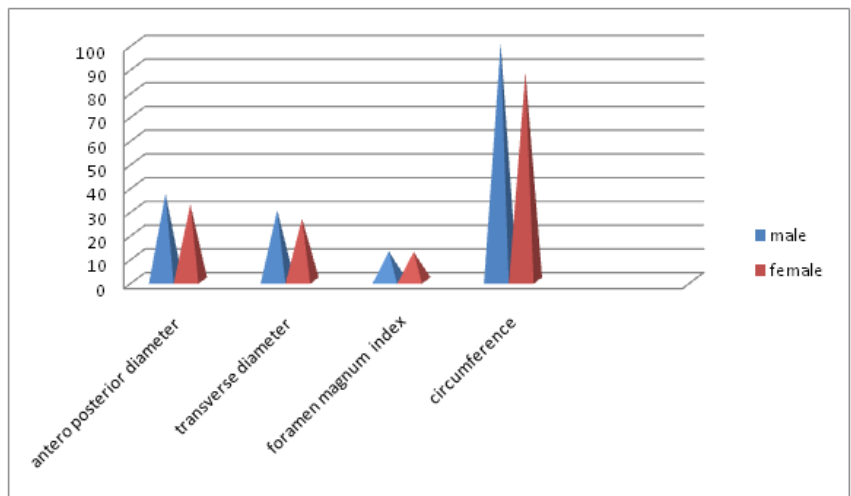

Figure 3: Morphometric analysis of the foramen magnum

\section{Discussion}

Gender determination in human skulls is based on morphological features especially the size, shape, and strength of certain structures which may also show ethnic variation in each population group which are influenced by certain factors like genes, environment and socioeconomic status. ${ }^{[15,16]}$

The oval shape of the foramen magnum was predominant in the present study which is similar to the other Indian studies by Radhakrishna S et al., and Sampada PK et al., Development of a particular shape of the foramen magnum is based on the ossification of primordial cranial residues, which later join the endochondral ossification points in different locations may result in various shapes. ${ }^{[17-19]}$

In the present study all the parameters anteroposterior diameter, transverse diameter, circumference, surface area and index of the foramen magnum were showing sexual dimorphism with great significance, but in a Brazilian study, the anteroposterior diameter was not showing any significant difference between male and female skulls. ${ }^{[20]}$

The average antero-posterior diameter of the foramen magnum of male skulls was higher than the other two Indian studies by Arpan et al., (Madhya Pradesh Population) and Routal Pal et al., (Gujarat Population), but the average anteroposterior diameter of female skulls of the present study was similar to these studies. ${ }^{[21-22]}$

The anteroposterior diameter of females was much lower than the all other ethnic groups. The anteroposterior diameter of males was higher than the Brazillian, Spanish, British, Gujarat region of India and Madhya Pradesh of India and lower than the Turkish population. The transverse diameter of males was similar with all the other ethnic population groups, but the females were little smaller than all the other studies. ${ }^{[20-23]}$

The circumference of the foramen magnum in the present study in males and females was $100.1 \mathrm{sq} \mathrm{mm}$ and $88.8 \mathrm{sq}$ $\mathrm{mm}$ respectively. The circumference of the male population of the present study was higher than the Iraq population Herrera reported as $99.3 \mathrm{sq} \mathrm{mm}$, whereas the female population of the present study shows much lower than the Iraq population which was $92.6 \mathrm{sq} \mathrm{mm.}{ }^{[24]}$ The studies done on the circumference of foramen magnum was very limited. So could not compare with other ethnic populations.

\section{Conclusion}

The results demonstrated that sexual dimorphism is present in the foramen magnum. In incomplete skeletons, metric analysis of the foramen magnum may provide a statistically useful indication as to sex of the unknown skull.

\section{References}

1. Holland TD. Race Determination of Fragmentary Crania by Analysis of the Cranial Base. Journal of Forensic Sciences1986a; 31(2):719725 .

2. Holland TD. Sex Determination of Fragmentary Crania by Analysis of the Cranial Base. American Journal of Physical Anthropology1986b; 70(2):203-208.

3. Holland TD. Use of the Cranial Base in the Identification of Fire Victims. Journal of Forensic Sciences1989; 34(2): 458-460.

4. Ferreira FV, Rosenberg B, da Luz HP. The Foramen Magnum index in Brazilians. Rev. Fac. Odontol. Sao Paulo, 1967; 5(4): 297-302. 
5. Teixeira WRG. Sex identification utilizing the size of the foramen magnum. American Journal of Forensic Medicine and Pathology.1982; 3: 203-206.

6. ZadvornovIu N. Variations in the shape of the foramen magnum and the structure of its posterior border . Arkh. Anat. Gistol. Embriol., 1972; 63(7): 42-50.

7. Manoel C, Prado FB, Caria PHF, Groppo FC. Morphometric analysis of the foramen magnum in human skulls of brazilian individuals: its relation to gender . Braz. J. Morphol. Sci 2009; 26(2): 104-108.

8. Ukoha U, Egwu OA, Okafor IJ, Anyabolu AE, Ndukwe GU, Okpala I. International Journal of Biological Medical Research. 2011; 2(4): 878-881.

9. Suazo GIC, Russo PP, Zavando MDA, Smith RL, Sexual dimorphism in foramen magnum dimensions. International Journal of Morphology; 2009; 27(1): 21-23.

10. Joy O, Ahmed E, Gabriel O, Ezon-ebidor E. Anthropometric study of the facial and nasal length of adult Igbo ethnic group in Nigeria. Internet J Biol Anthropol 2009; 2(2).

11. Zaidi SH, Dayal SS. Variations in the shape of foramen magnum in Indian skulls. AnatAnz Jena 1988; 167: 338-40

12. Henriquez-Pino J, Cricenti SV, Didio LJA. Morfometria del foramen magno y surelación con el tipo de cráneo en individuosbrasileños. Rev. Chil. Anat.1995; 13(2): 159-64.

13. Gunay $\mathrm{Y}$, Altinkok M. The value of the size of foramen magnum in sex determination. Journal of Clinical Forensic Medicine. 2000; 7: 147-149.

14. Murshed KA, Çìçekçibasi AE, Tuncer I. Morphometric Evaluation of the Foramen Magnum and Variations in its Shape: A Study on Computerized Tomographic Images of Normal Adults.Turkish Journal of Medical Sciences. 2003; 33(1): 301-306.

15. Rosing FW., Graw M., Marre B. et al. Recommendations for the forensic diagnosis of sex and age from skeletons. Homo. 2007; 58:75-
89.

16. Saunders SR. and Yang D. Sex determination: XX or XY from the human skeleton. In Fairgrieve SI. (Ed.).Forensic osteological analysis. Springfield: Charles C. Thomas. 1999: 36-59.

17. Radhakrishna S, Shivarama C, Ramakrishna A, Bhagya B. Morphometric analysis of foramen magnum for sex determination in south Indian population. Nite university journal of health science. 2012;2(1):20-22.

18. Sampada P K, Poornima B, Mallikarjun M, Santosh B Sakri. Morphometric and morphological study of foramen magnum in dried human skull bones. Int J Anat Res 2017;5(2.1):3682-86.

19. Govsa F, Ozer MA, Celik S, Ozmutaf NM. Three-Dimensional Anatomic Landmarks of the Foramen Magnum for the Craniovertebral Junction. The journal of Craniofacial Surgery. 2011;22(3):1073-1076.

20. Manoel C, Prado FB, Caria PHF. And Groppo FC. Morphometric analysis of the foramen magnum in human skulls of brazilian individuals: its relation to gender. Braz. J. Morphol. Sci., 2009;26(2):104-108.

21. Arpan Dubey, S K Verma. The anatomy of occipital condyles and foramen mgnum and their surgical importance: A morphometric study. Int J Anat Res 2017; 5(2.1): 3780-83.

22. Routal RR., Pal GP., Bhagwat SS. et al. Metrical studies with sexual dimorphism in foramen magnum of human crania. Journal of the Anatomical Society of India. 1984;2(33):85-89.

23. Herrera CJC. Study of the anatomic metric values of the foramen magnum and its relation to sex. Acta Anatomica. 1987;130:344-347.

24. AT Uthman, NH Al-Rawi and JF Al-Timimi. Evaluation of foramen magnum in gender determination using helical CT scanning. Dentomaxillofacial Radiology 2012; 41:197-202.

Copyright: () the author(s), 2019. It is an open-access article distributed under the terms of the Creative Commons Attribution License (CC BY 4.0), which permits authors to retain ownership of the copyright for their content, and allow anyone to download, reuse, reprint, modify, distribute and/or copy the content as long as the original authors and source are cited.

How to cite this article: Kumari P, Kumar A, Kumar S, Ranjan SK. Evaluation of Sexual Dimorphism of Foramen Magnum: A Morphometric Study . Asian J. Med. Res. 2019; 8(3):FM10-FM12.

DOI: dx.doi.org/10.21276/ajmr.2019.8.3.FM4

Source of Support: Nil, Conflict of Interest: None declared. 